American J. of Engineering and Applied Sciences 2 (1): 139-146, 2009

ISSN 1941-7020

(C) 2009 Science Publications

\title{
Effect of Microwave and Ultrasonic Pretreatments on Biogas Production from Anaerobic Digestion of Palm Oil Mill Effleunt
}

\author{
${ }^{1}$ Saifuddin, N. and ${ }^{2}$ S.A. Fazlili \\ ${ }^{1}$ Chemistry Unit, ${ }^{2}$ Physics Unit, Department of Engineering Sciences, \\ College of Engineering, University Tenaga Nasional, 43900 Serdang, Selangor, Malaysia
}

\begin{abstract}
Problem Statement: Oil palm production is a major agricultural industry in Malaysia. In 2006, palm oil mills in Malaysia produced more than 58 million tonnes of Palm Oil Mill Effluent (POME). Existing treatment in a series of open lagoons at high ambient temperatures, results in the uncontrolled production of methane and carbon dioxide, which are both green house gases (GHGs). With the increased worldwide concern on environmentally friendly production processes particularly the emission of methane, it is important to develop an alternative concept for POME treatment. This study elucidates the effects of pre-treatment of palm oil mill effluent by microwave irradiation and ultrasonic on anaerobic digestion. Approach: Effects of pre-treatment on sludge characterisation parameters were monitored. The Soluble Chemical Oxygen Demand (SCOD)/total COD ratio and biodegradability of soluble organic matter increased significantly after both the pre-treatments which indicated an increase in disintegration of the floc structure of the sludge. Three identical bioreactors with working volume of 5 litres were used as anaerobic digesters at $32-35^{\circ} \mathrm{C}$. The reactors were separately fed with pre-treated sludge (microwave, ultrasonic and combination of microwave and ultrasonic) and control sludge at different Hydraulic Retention Times (HRT) to check for the production of methane. Results: The maximum SCOD/TCOD ratio reached almost 29\% after $30 \mathrm{~min}$ of ultrasonic treatment, while it was $45 \%$ after $7 \mathrm{~min}$ of microwave irradiation. The $\mathrm{BOD}_{5} / \mathrm{SCOD}$ ratio also increased after the pre-treatments suggesting the biodegradability of the soluble organic material increased during the treatment. It was observed that TVFA released was increased after both the treatments, with microwave treatment showing a higher yield of TVFA. Greatest enhancement in methane production was shown by the 3 min microwave plus $10 \mathrm{~min}$ ultrasonic treatment. Conclusion: The microwave in combination with ultrasonic would be a rapid and economical method for sludge pre-treatment for enhancement of biogas production.
\end{abstract}

Key words: Anaerobic digestion, microwave pretreatment, ultrasonic pre-treatment, methane, Palm Oil Mill Effluent (POME)

\section{INTRODUCTION}

Many branches of agriculture and food industries such as dairy, edible oil, fat refining, slaughterhouse, wool scouring and meat processing plants have a considerable wastewater output. The problem of pollution is not caused only by the total amount of wastewater production, but also by the content of organic matter. The bioprocesses that will be used to treat wastewater in the future will be focused on the need to exploit resources rather than only pollution control. Many bioprocesses can provide bioenergy or valuable chemicals while simultaneously achieving the objective of pollution control. Industrial wastewaters, for example, from food-processing industries and breweries and agricultural wastewaters from animal confinements are ideal candidates for bioprocessing because they contain high levels of easily degradable organic material, which results in a net positive energy or economic balance, even when heating of the liquid is required. Such wastewaters are potential commodities from which bioenergy and biochemicals may be produced. Recovery of energy and valuable materials might reduce the cost of wastewater treatment and some what reduce our dependence on fossil fuels ${ }^{[1]}$. Anaerobic digestion is a natural process in which bacteria convert organic materials into biogas. Biogas can be collected and used as a potential energy resource.

Corresponding Author: Saifuddin, N., Chemistry Unit, Department of Engineering Sciences, College of Engineering, University Tenaga Nasional, 43900 Serdang, Selangor, Malaysia 
Am. J. Engg. \& Applied Sci., 2 (1): 139-146, 2009

Table 1: Characteristics of raw $\mathrm{POME}^{[4]}$ and the regulatory discharge limits ${ }^{[14]}$

\begin{tabular}{lll}
\hline Parameter & $\begin{array}{l}\text { Value (All values, except } \mathrm{pH} \text { and temperature, } \\
\text { (all values, except } \mathrm{pH} \text { expressed in } \mathrm{mg} / \mathrm{L} .)\end{array}$ & $\begin{array}{l}\text { Regulatory discharge limit (All values, except } \mathrm{pH} \\
\text { and temperature, are expressed in mg/L.) }\end{array}$ \\
\hline Temperature $\left({ }^{\circ} \mathrm{C}\right)$ & $80-90$ & 45 \\
$\mathrm{pH}$ & 4.7 & $5.0-9.0$ \\
Biochemical Oxygen Demand & 25,000 & $100(50)^{(\mathrm{b})}$ \\
$\left(\right.$ BOD3, 3 days at $30^{\circ} \mathrm{C}^{(\mathrm{a})}$ & & \\
Chemical Oxygen Demand (COD) & 50,000 & - \\
Total Solids (TS) & 40,000 & - \\
Total Suspended Solids (TSS) & 18,000 & 400 \\
Total Volatile Solids (TVS) & 34,000 & - \\
Oil And Grease (O\&G) & 4,000 & 50 \\
Ammonia-Nitrogen (NH3-N) & 35 & $150^{(\mathrm{c})}$ \\
Total Kjeldahl Nigrogen (TKN) & 750 & $200^{(\mathrm{c})}$ \\
\hline
\end{tabular}

(a) Statutory incubation conditions. (b) This additional limit is the arithmetic mean value determined on the basis of a minimum of four samples taken at least once a week for four weeks consecutively. (c) Value of filtered sample.

Oil palm production is a major agricultural industry in Malaysia. In 2006, there were more than 4.2 million hectares of oil palm plantations which produced 16 million tonnes of oil ${ }^{[2]}$. In total, about 110 million tonnes of renewable non-oil biomass (trunk, fronds, shells, palm press fiber and the empty fruit bunches) are produced each year. Furthermore approximately 0.65 tonnes of raw palm oil mill effluent (POME) is produced for every ton of fresh fruit bunches. In 2006, palm oil mills in Malaysia produced more than 58 million tonnes of $\mathrm{POME}^{[2]}$. POME is an acidic brownish colloidal suspension characterized by high contents of organics and solids and is discharged at a temperature of $80-90^{\circ} \mathrm{C}$ (Table 1 ). It has been estimated that POME contributes to about $30 \%$ of the total biochemical oxygen demand (BOD) load exerted on the Malaysian aquatic environment. Wastewater treatment facility is one of the most important components in the palm oil industry. This facility is normally used to treat a large volume of POME generated during the production of Crude Palm Oil (CPO) before the effluent is safely discharged to the surrounding environment through water canal or river. Specifically, the amount of POME generated is approximately $3.8 \mathrm{~m}^{3}$ for each ton of CPO produced ${ }^{[3]}$. The problems associated with aerobic treatment of POME using a pond system are long retention time (90-120 days), large area requirement, high demand for maintenance, loss of nutrition and high emission of methane. Since methane is a greenhouse gas which is 21 times stronger than carbon dioxide, open ponds result in significant emissions of greenhouse gases. Existing treatment in a series of open lagoons at high ambient temperatures, results in the uncontrolled production of methane and carbon dioxide, which are both Green House Gases (GHGs). With the increased worldwide concern on environmentally friendly production processes particularly the emission of methane, it is important to develop an alternative concept for POME treatment ${ }^{[4]}$. Anaerobic digestion is considered to be an effective treatment process for POME. If the POME is treated in an anaerobic digesting plant instead, the methane produced will be available for energy purposes. There have been growing interests in recovering biogas/methane from POME treatment as a clean renewable gaseous fuel for steam, power generation or other applications. Based on the gross annual CPO production of Malaysia of 14 million tonnes for 2004, the estimations made have shown a potential total methane recovery of 524,000 tones. With increasing demand for energy and cost effective environmental protection, anaerobic digestion biotechnology has become the focus of worldwide attention ${ }^{[5]}$. Moreover, it offers a positive environmental impact since it combines waste stabilization with net fuel production.

An anaerobic degradation of particulate organics is considered to be a sequence of three steps: hydrolysis, acidogenesis and methanogenesis. Among these, biological hydrolysis of the particulate organics has been considered to be a rate limiting step ${ }^{[6]}$. Because the sludge particles consist mainly of a polymeric network formed by extracellular polymeric substances and microbial cells that are resistant to direct anaerobic degradation since cell walls and extracellular polymeric substances present physical and chemical barriers ${ }^{[7]}$. It is widely documented that pre-treatment methods such as $^{[8-13]}$, cause the lyses or degradation of sludge cells and particulates, the organic matter therefore becoming more accessible to anaerobic microorganisms. The efficiency of pre-treatment is commonly evaluated in terms of biodegradability or biogas production.

The next two stages in an anaerobic digestion are acidogenesis and methonegenesis. During the acid phase, bacteria convert complex organic compounds 
(carbohydrates, fats and proteins) to simple organic compounds, mainly short-chain volatile organic acids (acetic, propionic and lactic acids). Subsequently, several species of strictly anaerobic bacteria (methanogenic microorganisms) called "methane formers" convert the acetate, hydrogen and carbon dioxide into methane gas $\left(\mathrm{CH}_{4}\right)$. This process is referred to as methanogenesis. During this phase, waste stabilization occurs, represented by the formation of methane gas.

The aim of the present study was to examine the effects of acidic, microwave (an electromagnetic radiation with an oscillation frequency of $0.3-300$ GHz.) and ultrasound pre-treatments as a cost effective and rapid technique for the sludge pre-treatment for enhancement of anaerobic digestion of POME. The alternating electric field by microwave irradiation causes a rapid alignment and realignment of dipoles in a polar solvent. Continuous repetition of alignment and realignment generates friction, thus resulting in heat generation $^{[15]}$. Tsai ${ }^{[16]}$ also reported that microwave method for cell lyses was fast and had many potential applications. Ultrasonic technology is a safe, clean and effective method to cause degradation of organics or cell lyses ${ }^{[17-19]}$. Therefore ultrasound can be used and integrated with other pre-treatment method for enhancement of anaerobic digestion. Because of the high energy demands of the processes, their energy balances were also examined.

\section{MATERIALS AND METHODS}

The waste water from the palm oil mill known as Palm Oil Mill Effluent (POME) was obtained from Seri Ulu Langat Palm Oil Mill Sdn. Bhd., in Dengkil, Selangor. The fresh POME collected from the mill was brought to the lab and was stored at $4^{\circ} \mathrm{C}$ in tightly closed plastic containers until used.

Pre-Treatments: Total Volatile Solid (TVS) of the POME was determined as standard method Clescerl $e t$ $a l .{ }^{[20]}$ Well-mixed samples were filtered through a preweighed $\mathrm{GF} / \mathrm{C}$ fibreglass filter and the residue retained on the filter was dried overnight to a constant weight in a $105{ }^{\circ} \mathrm{C}$ oven. The increase in weight of the filter represented the Total Solids (TS) portion. The dried filter was ignited at $550{ }^{\circ} \mathrm{C}$ in a muffle furnace for $20 \mathrm{~min}$. The difference between ash and dry weights represented the fixed fraction of the sample and the difference between the TS and the fixed fraction was considered to be the TVS portion. The typical value for TVS for POME was around 32-34 $\mathrm{g} \mathrm{L}^{-1}$. For all experiments the TVS of the POME was adjusted to around $2 \%$ (dilution with distilled) for the subsequent experiments. The initial temperature of sludge was maintained at $10^{\circ} \mathrm{C}$. The applied pre-treatments were performed separately to each sample of POME prior to batch experiments.

A microwave oven $(2450 \mathrm{MHz}, 700 \mathrm{~W})$ was used to irradiate the sludge. A series of experiments were performed at different irradiation times of 0 (control), 3 , $5,7,9,11$ and $15 \mathrm{~min}$ to evaluate the degree of disintegration of organics in the sludge. Lab-scale ultrasonic treatments were applied to sample of POME at $10^{\circ} \mathrm{C}$. In this setup, sample in batches of $200 \mathrm{~mL}$ each were sonicated using Cole-Parmer 130-Watt Ultrasonic processor (transducer: lead zirconate titanate piezoelectric). The frequency was $18 \mathrm{kHz}$ and power input was adjusted between 0 to100 W. Different ultrasonic intensity $\left(0.20,0.30\right.$ and $\left.0.50 \mathrm{~W} \mathrm{~mL}^{-1}\right)$ and sonication time $(1,5,10$ and $30 \mathrm{~min})$ were applied. The transducer was mounted on a retort stand and the probe was lowered into the sludge. The beaker containing the sludge was placed on a magnetic stirrer. For combined ultrasonic and microwave pre-treatment, the samples were sonicated as mentioned above using $0.20 \mathrm{~W} \mathrm{~mL} \mathrm{~m}^{-1}$ intensity for 10 and $30 \mathrm{~min}$. After which each samples were subjected to microwave irradiation $(2450 \mathrm{MHz}$, $700 \mathrm{~W}$ ) for 3 and $7 \mathrm{~min}$.

After the pre-treatment process Chemical Oxygen Demand (COD), Biochemical Oxygen Demand (BOD) and Total Volatile Fatty Acids (TVFA) were measured using standard methods ${ }^{[20]}$. Biogas production tests were performed in batch mode under mesophilic conditions, at $30{ }^{\circ} \mathrm{C}$ in an anaerobic digester

Batch Anaerobic digestion: The experiments were performed using three well - mixed digesters. The digesters were mainly modified spinner flasks (Corning Proculture). The spinner flasks were of $10 \mathrm{~L}$ capacity and had a wide mouth $(120 \mathrm{~mm})$ and two angled arms (45 mm), which serve as liquid and gas sampling ports. Volumes of POME used were $5 \mathrm{~L}$ and the $\mathrm{pH}$ was maintained at 7.2. Temperature was maintained at 32$37^{\circ} \mathrm{C}$ using the hot plate and were well mixed using the magnetic bar stirrer. Hydraulic retention time (HRT) of $15,12,10,8,4$ and 2 days were sequentially tried to investigate the performance of the anaerobic digestion of the pre-treated POME. There were total of 3 pretreated sample; the microwave treated $(3 \mathrm{~min})$, the ultrasonic treated $(10 \mathrm{~min})$ and combination of both treatment (3 min microwave+10 min ultrasonic). A control reaction was performed using untreated POME. To obtained anaerobic condition, oxygen was removed by purging the headspace of the bottles with nitrogen gas for five min, after which the bottles mouth were capped tightly. The biogas was collected via the side arm (gas sampling port) which was connected to the graduated glass cylinder. Biogas production (volume) 
was measured by using water displacement method of acidified water $(\mathrm{pH} 2-3)$ and its methane content by $\mathrm{KOH}$ solution displacement in a serum bottle, as described previously ${ }^{[21]}$.

\section{RESULTS}

Table 2 summarizes the effect of microwave irradiation on sludge disintegration. The ratio of SCOD to TCOD increased as microwave irradiation time increased. This indicated that various cytoplasmic materials of the sludge were released into the medium as a result of cell wall disintegration. The samples began to over boil after $7 \mathrm{~min}$ of microwave irradiation and this duration was used in other studies.

The variations of SCOD/TCOD ratio under different ultrasonic treatments were studied. Fig. 1 and 2 represent separately the effects on SCOD/TCOD ratio under different ultrasonic intensity and sonication time respectively. Judging from these results, the most important parameter is sonication time. The ultrasonic intensity could barely influence the SCOD/TCOD ratio, this phenomena is coincident with other observations in this study. The maximum ratio of SCOD/TCOD reached about 0.32 after $30 \mathrm{~min}$ treatment, (using intensity of 0.5 $\mathrm{W} \mathrm{mL}{ }^{-1}$ ) while the ratio was about 0.29 after $30 \mathrm{~min}$ treatment (using intensity of $0.20 \mathrm{~W} \mathrm{~mL}{ }^{-1}$ ). Hence, for the purpose of saving energy, the lowest power density $\left(0.20 \mathrm{~W} \mathrm{~mL} \mathrm{~mL}^{-1}\right)$ was sufficient and was employed throughout.

The use of pre-treatments especially microwaves and ultrasonic is a promising method for sludge disintegration, because of the rapid internal heating. A further strategy was to study the combined effects of both ultrasonic/microwave pre-treatments. Ultrasonic pre-treatment (using $0.20 \mathrm{~W} \mathrm{~mL}^{-1}$ ) for 10 and $30 \mathrm{~min}$ followed by a 3 and $7 \mathrm{~min}$ of microwave irradiation ( $2450 \mathrm{MHz}$ and $700 \mathrm{~W}$ ) showed increase in the ratios of $\mathrm{SCOD} / \mathrm{TCOD}$ and $\mathrm{BOD}_{5} / \mathrm{SCOD}$ as shown in Fig. 3 and 4. It was found that the combined ultrasonic/microwave pre-treatment increased the SCOD/TCOD ratio denoting that the release of organic materials from solid state to liquid (soluble), while $\mathrm{BOD}_{5} / \mathrm{SCOD}$ ratio also increased suggesting the biodegradability of the soluble

Table 2: Effect of microwave irradiation on sludge disintegration

\begin{tabular}{lllll}
\hline $\begin{array}{l}\text { Microwave } \\
\text { irradiation } \\
\text { time }(\mathrm{min})\end{array}$ & $\begin{array}{l}\text { Microwave } \\
\text { irradiation } \\
\text { energy }(\mathrm{kJ} / \mathrm{l})\end{array}$ & $\begin{array}{l}\text { Final } \\
\text { temperature } \\
\left({ }^{\circ} \mathrm{C}\right)\end{array}$ & $\mathrm{SCOD} / \mathrm{TCOD}$ & $\mathrm{BOD}_{5} / \mathrm{SCOD}$ \\
\hline 0 & 0 & 10.0 & 0.11 & 0.44 \\
3 & 252 & 59.4 & 0.21 & 0.56 \\
5 & 420 & 78.1 & 0.29 & 0.78 \\
7 & 588 & 91.8 & 0.45 & 0.93 \\
9 & 756 & boiled & 0.69 & 0.95 \\
11 & 924 & boiled & 0.77 & 0.95 \\
\hline
\end{tabular}

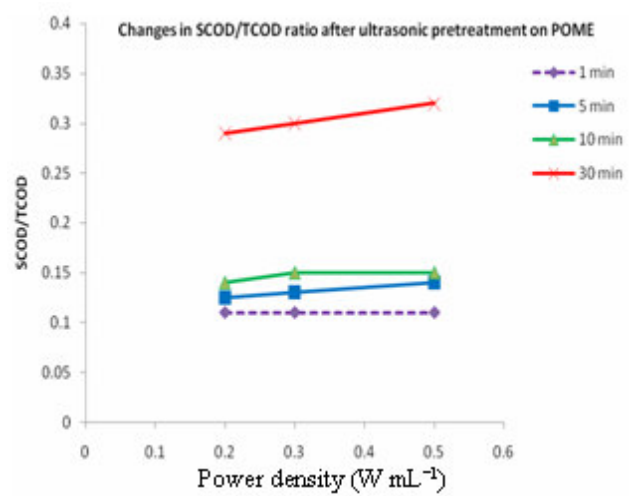

Fig. 1: Effect of ultrasonic pre-treatment on the SCOD/TCOD ratio at four different length of sonication time each with three different sonication intensity

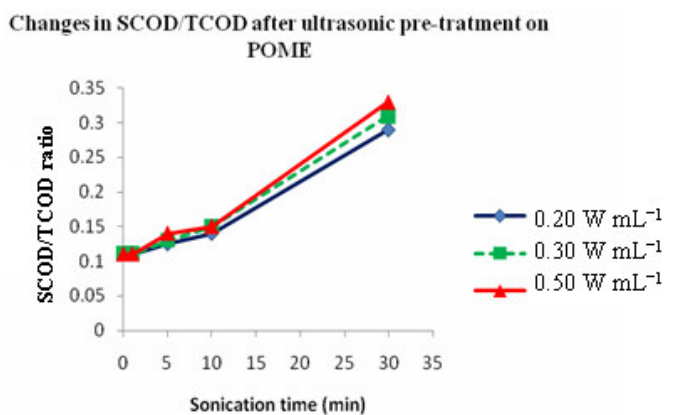

Fig. 2: The same data on effect of ultrasonic pretreatment on the SCOD/TCOD ratio as in Fig. 1 but plotted against sonication time.

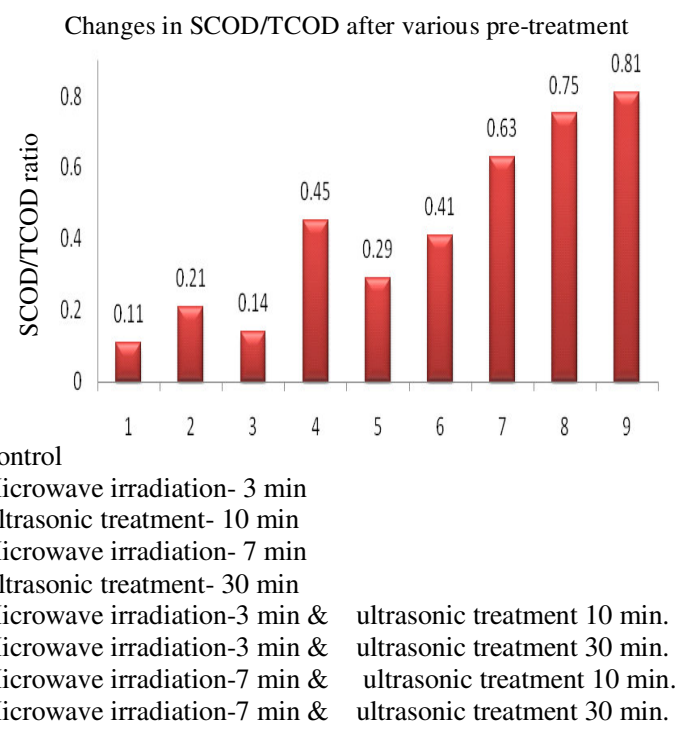

Fig. 3: Effects of combined pre-treatments of ultrasound and microwave on the ratio of SCOD/TCOD 


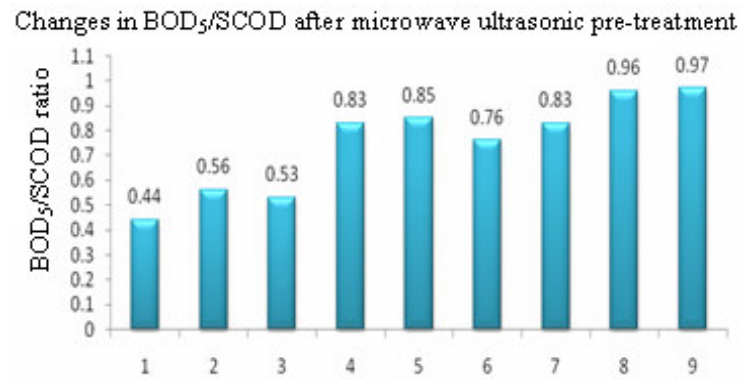

1. Control

2. Microwave irradiation- $3 \mathrm{~min}$

3. Ultrasonic treatment- $10 \mathrm{~min}$

4. Microwave irradiation- $7 \mathrm{~min}$

5. Ultrasonic treatment- $30 \mathrm{~min}$

6. Microwave irradiation-3 min \& ultrasonic treatment $10 \mathrm{~min}$.

7. Microwave irradiation-3 $\mathrm{min} \&$ ultrasonic treatment $30 \mathrm{~min}$.

8. Microwave irradiation-7 min \& ultrasonic treatment $10 \mathrm{~min}$

9. Microwave irradiation-7 min \& ultrasonic treatment $30 \mathrm{~min}$.

Fig. 4: Effects of combined pre-treatments of ultrasound and microwave on the ratio of $\mathrm{BOD}_{5} / \mathrm{SCOD}$

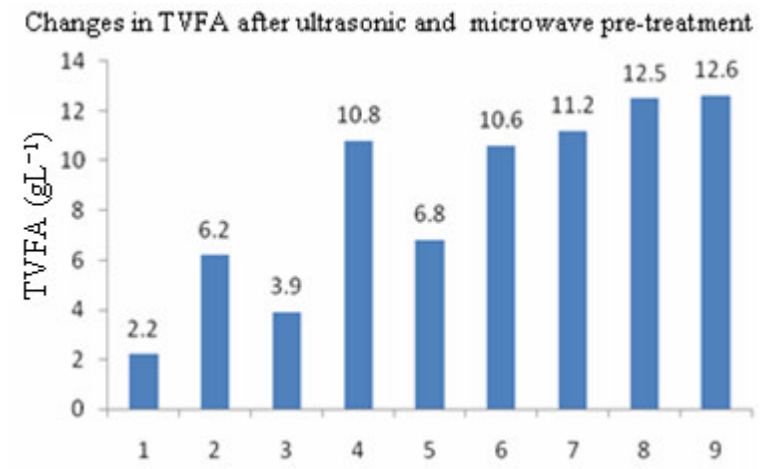

1. Control

2. Microwave irradiation- $3 \mathrm{~min}$

3. Ultrasonic treatment- $10 \mathrm{~min}$

4. Microwave irradiation- $7 \mathrm{~min}$

5. Ultrasonic treatment- $30 \mathrm{~min}$

6. Microwave irradiation-3 min \& ultrasonic treatment $10 \mathrm{~min}$.

7. Microwave irradiation- $3 \mathrm{~min} \&$ ultrasonic treatment $30 \mathrm{~min}$.

8. Microwave irradiation-7 min \& ultrasonic treatment $10 \mathrm{~min}$

9. Microwave irradiation-7 min \& ultrasonic treatment $30 \mathrm{~min}$.

Fig. 5: Effects of combined pre-treatments of ultrasound and microwave on the Total Volatile Fatty Acid (TVFA) produced

organic materials increased during the treatment. As shown in Fig. 4, there was significant difference between the effects produced by the combined ultrasonic treatment for $10 \mathrm{~min}$ or $30 \mathrm{~min}$ followed by microwave irradiation for $7 \mathrm{~min}$ as compared with the effects produced individually by $30 \mathrm{~min}$ ultrasonic or 7 min microwave irradiation. The highest increase was
Rate of Methane gas production after microwave and ultrasonic pretreatment

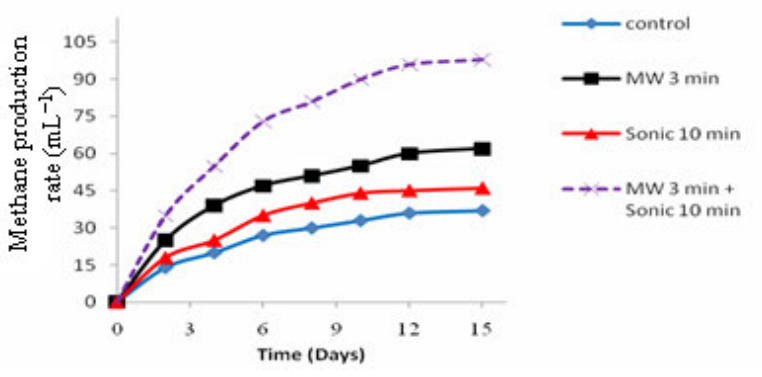

Fig. 6: The difference in methane production between the various pre-treated and control samples. (MW-denotes microwave treatment and Sonicmeans ultrasonic treatment)

obtained by $10 \mathrm{~min}$ ultrasonic followed by $7 \mathrm{~min}$ microwave treatment.

Figure 5 depicts variations in total volatile fatty acids (TVFA) after ultrasonic and microwave treatment under different exposure times. The TVFA release is becoming obvious with the increase of sonication and microwave exposure time. It is observed that the microwave treatment shows a higher yield of TVFA as compared to ultrasonic treatment.

The use of pre-treatments especially microwaves and ultrasonic is a promising method for sludge disintegration, because of the rapid internal heating. The cell walls of both dead and living microorganisms in sludge are destroyed and the organic substances are digested due to the

The biogas production rate as a function of operational time at the given hydraulic retention times (HRT) is shown in Fig. 6. The biogas production was measured according to the method described previously $^{[21]}$. The untreated sludge was used as control sample. The results in Fig. 6 revealed that all types of pre-treatment enhanced the methane production relative to the control ( $\max 40 \mathrm{~mL}^{-1}$ after 15 days).

The energy requirement for the pre-treatment processes can be assessed by estimating the amounts energy per unit mass of the sludge required to achieve a certain volume of methane (vol. of methane produced per litre sludge after 15 days). Table 3 shows the comparison of energy requirement for sludge disintegration using microwave and ultrasonic pretreatment using data from the Fig. 6.

In the ultrasonic pre-treatment, approximately 44 $\mathrm{mL}$ of methane was produced after $10 \mathrm{~min}$ of treatment, which was equivalent to energy consumption of $120 \mathrm{~kJ}$ per litre sludge. This accounted to $19 \%$ increase in 
Table 3: Comparison of microwave (MW) and ultrasonic (Sonic) pretreatment for methane production

\begin{tabular}{|c|c|c|c|c|}
\hline & Control & $\begin{array}{l}\text { Microwave } \\
(2,450 \mathrm{MHz}, \\
700 \mathrm{~W})\end{array}$ & $\begin{array}{l}\text { Ultrasonic } \\
(20 \mathrm{kHz} \text {, } \\
100 \mathrm{~W}) \\
20 \mathrm{kHz} \\
100 \mathrm{~W}))\end{array}$ & $\begin{array}{l}\text { Microwave plus } \\
\text { Ultrasonic }(2,450 \\
\text { MHz, } 700 \mathrm{~W}+\text {, }\end{array}$ \\
\hline POME volume & $500 \mathrm{~mL}$ & $500 \mathrm{~mL}$ & $500 \mathrm{~mL}$ & $500 \mathrm{~mL}$ \\
\hline Treatment time & 0 & $3 \mathrm{~min}$ & $10 \mathrm{~min}$ & $\begin{array}{l}3 \mathrm{~min}(\mathrm{MW}) \\
+10 \mathrm{~min} \\
\text { (Sonic) }\end{array}$ \\
\hline $\begin{array}{l}\text { Specific energy } \\
\text { (KJ/L-sludge) }\end{array}$ & 0 & 252 & 120 & 372 \\
\hline $\begin{array}{l}\text { Methane } \\
\text { Produced per litre } \\
\text { sludge after } 15 \text { da }\end{array}$ & $\mathrm{e}^{37 \mathrm{~mL}}$ & $58 \mathrm{~mL}$ & $44 \mathrm{~mL}$ & $98 \mathrm{~mL}$ \\
\hline
\end{tabular}

methane production over the control. However, $58 \mathrm{~mL}$ of methane (56.7\% higher than control) was produced from $1 \mathrm{~L}$ of sludge after 3 min of microwave irradiation with energy consumption of $252 \mathrm{~kJ}$ per litre sludge. By using the assumption that the enhancement effect is linearly proportional with the duration of treatment, then we can assume that for $360 \mathrm{~kJ}$ ( 3 x 120) of energy input using ultrasonic treatment, the methane production would be about $57 \%$ higher than the control.

\section{DISCUSSION}

The physico-chemical parameters of POME used in this study were typically the same as reported in Table $1^{[4]}$. Most palm oil mills in Malaysia have similar operations and the wastewater discharged is quite typical as seen in previous reports ${ }^{[22,23]}$. Since the COD/BOD ratio of POME is about 1.8-2.0 a good possibility exists that the organic matter is biodegradable ${ }^{[24]}$. The main recalcitrant organic material found in POME as mentioned previously is lignocelluloses $^{[25]}$. There is also a significant amount of oil and grease, which can be hydrolyzed by microorganisms to fatty acids. Some of these fatty acids are potential substrates for methane production which does allow a favourable economic outcome ${ }^{[26]}$. In contrast, there have been reports that lipid-rich waste contains long chain fatty acids, especially palmitate (higher than $50 \mathrm{mg} \mathrm{G}^{-1}$ dry weight) and oleate (higher than $200 \mathrm{mg} \mathrm{L}^{-1}$ ), that were hydrolysis products of fat $\&$ oil, can inhibit bacterial growth and hence methane formation $^{[27]}$. The high amounts of TS and TSS in the POME comes from insoluble organic substances being washed out during the production process.

Soluble COD (SCOD) displays the organic matter only in the liquid portion of the sludge while total COD (TCOD) reflects the organic matter in both the solid and liquid state of the sludge. TCOD should be stable for the same sludge sample. Then, the increase of SCOD/TCOD ratio denotes the release of the organic materials from solid state to liquid state after pretreatment treatment. With the increase of sonication time, there is an increase in the disintegration of floc structure, hence the rise of SCOD/TCOD ratio caused by the release of extracellular polymeric substances (EPS), which consists of polysaccharides, proteins and other macromolecule embedded in the floc matrix ${ }^{[28]}$. Further increase could also be contributed by the release of soluble organics from the disrupted cells.

Pre-treatments especially microwaves and ultrasonic is a promising method for sludge disintegration, because of the rapid internal heating. The cell walls of both dead and living microorganisms in sludge are destroyed and the organic substances are digested due to the heat effect. Volatile fatty acids (VFA) are fatty acids with a carbon chain of six carbons or fewer. Volatile fatty acids are very important part of the organic substances, which is easily absorbed by microorganisms, hence would be very important for the methane production during anaerobic digestion. As noted earlier (Table 2) the $\mathrm{BOD}_{5} / \mathrm{SCOD}$ ratio of the original POME was around 0.44. The ratio increased quickly with the microwave pre-treatment as shown in Table 2. Similarly the $\mathrm{BOD}_{5} / \mathrm{SCOD}$ ratio increase quickly with the sonication time. Using intensity of $0.20 \mathrm{~W} / \mathrm{mL}$ and $10 \mathrm{~min}$ of sonication time, the ratio was 0.66. After $30 \mathrm{~min}$ of sonication $\left(0.20 \mathrm{~W} \mathrm{~mL}^{-1}\right)$ the ratio was 0.91 . Hence biodegradability of organic matters was improved drastically by both microwave irradiation and ultrasonic pre-treatments.

The combined effects of both ultrasonic/microwave pre-treatment was also studied. As shown in Fig. 4, the highest increase in $\mathrm{BOD}_{5} / \mathrm{SCOD}$ was obtained by 10 min ultrasonic followed by 7 min microwave treatment. It is noteworthy that any further increase in time of the pre-treatments for the combined method did not show any significant improvement on the biodegradability. From Fig. 5, it can be observed that ultrasound will help to release the extracellular polymeric substances which among others consist of short chain organic matters embedded in the floc matrix due to effective disintegration of the floc structure ${ }^{[28]}$. Larger molecules and longer chain fatty acids may require further treatment to break into volatile fatty acid. Microwave treatment produces higher TVFAs because the rapid internal heating destroys the cell walls of both leaving and dead microorganism in the sludge and the organic compounds are digested due to heat effect. During longer exposure to microwave heating some of the long 
fatty acid chains will also be broken down to short fatty acid chain. This will be beneficial because long chain fatty acids especially palmitate and oleate can inhibit bacterial growth and hence methane formation ${ }^{[27]}$. It is also interesting to note that the effects of both pretreatments are not cumulative, as can be seen from the microwave treatment at $7 \mathrm{~min}$ plus ultrasonic treatment at either $10 \mathrm{~min}$ or $30 \mathrm{~min}$ which gave about the same amount of TVFA.

From Fig. 6, it shows that there is a slight difference in the methane production between combined microwave $3 \mathrm{~min} /$ ultrasonic $10 \mathrm{~min}$ treatment (57\% higher as compared to control) compared to only the $3 \mathrm{~min}$ microwave treatment (43\% higher as compared to control). However the $7 \mathrm{~min}$ microwave plus 10 min ultrasonic treatment had the greatest enhancement, increasing the methane production by slight more than $103 \%$ as compared to control. It could be suggested that organics inside the cells were released as a result of cell lyses by microwave irradiation, thereby increasing their biodegradability over the control sludge. Therefore, pre-treated sludge became more susceptible for microbial attack primarily by acidogens than control sludge, thus providing better substrate for methanogens and enhancing the overall methane production rate. Sludge decomposition by microwave/ultrasound pretreatment could be divided into three phases based on the conversion of organic matter: floc structure disintegrating and particle size decrease phase, cell breakage and macromolecular compounds release phase and conversion of macromolecular compounds to Volatile Fatty Acids (VFAs) phase.

Studying the data in Table 3 which shows the comparison of energy requirement for sludge disintegration using microwave and ultrasonic pretreatment, we can see that by comparing similar amounts of methane produced, microwave pretreatment required lesser energy input as compared to with ultrasonic treatment $(42.8 \%$ lesser $)$. In the combined treatment (microwave $3 \mathrm{~min}+$ ultrasonic 10 $\min$ ), about $98 \mathrm{~mL}$ of methane was produced per litre sludge. This accounts for about $164 \%$ more methane compared to the control. The energy input for this combined treatment process was calculated to be 372 $\mathrm{kJ} / \mathrm{L}$-sludge. By the same assumption, if we were to achieve similar enhancement using ultrasonic alone, we need to multiply by factor of $8.6(19 \%$ x $8.6=163.4 \%)$, then the energy input would estimated to be $1032 \mathrm{~kJ} / \mathrm{L}-$ sludge. Again ultrasonic treatment alone is inefficient in terms of energy required. Finally by looking at microwave irradiation alone, as the method of pretreatment, to obtain about $164 \%$ enhancement, we need to multiply by factor of $2.9(56.7 \%$ x $2.9=164 \%)$, then the energy input would be estimated to be $730.8 \mathrm{~kJ} / \mathrm{L}-$ sludge.

\section{CONCLUSION}

It could be concluded that the microwave in combination with ultrasonic would be a rapid and economical method for sludge pre-treatment for enhancement of biogas production. However, microwave irradiation alone would require double the energy required by the combined method. Nevertheless this higher energy requirement can be offset if we look at the capital cost required to install both the systems. Hence, in terms of instrumentation cost, process design and maintenance, microwave treatment alone would also be a viable option.

\section{REFERENCES}

1. Angenet, L.T., K. Karim, M.H. Al-Dahhan, B.A. Wrenn and R. Domı'guez-Espinosa, 2004. Production of bioenergy and biochemicals from industrial and agricultural wastewater. Trends Biotechnol., 22 : 477-485. $\quad$ DOI: 10.1016/j.tibtech.2004.07.001

2. Choo, Y.M., 2007. Palm Biofuels: From research to commercialization. Malaysian Oil Sci. Tech., 16: 12-20.

3. Ma, A.N. and A.S.H. Ong, 1988. Treatment of palm oil steriliser condensate by an anaerobic process. Biol. Wastes, 23: 85-97.

4. Ma, A.N., 2000. Management of Palm Oil Industrial Effluents. In: Advances in Oil Palm Research, Basiron, Y., Jalani, B.S. and K.W. Chan, (Eds.). Bangi: Malaysian, Palm Oil Board, Ministry of Primary Industries Malaysia, Chap., pp: 1439-1461.

5. Yeoh, B.G., M.Y. Roslan and S.K. Quah, 1991. Optimising methane yield in anaerobic POME treatment through temperature and process manipulations. J. Indus. Technol., 1: 19-31.

6. Tiehm, A., K. Nickel, M. Zellhorn and U. Neis, 2001. Ultrasonic waste activated sludge disintegration for improving anaerobic stabilization. Wat. Res., 35: 2003-2009. DOI: 10.1016/S0043-1354(00)00468-1.

7. Higgins, M.J. and J.T. Novak, 1997. Characterization of exocellular protein and its role in bioflocculation. J. Environ. Eng., 123: 479-485. DOI 10.1061/(ASCE)0733-9372(1997)123:5(479)

8. Muller, J., G. Lehne, J. Schwedes, S. Battenberg, R. Naveke and J. Kopp, 1998. Disintegration of sewage sludges and influence on anaerobic digestion. Water Sci. Technol., 38: 425-433. 
9. Stuckey, D.C. and P.L. McCarty, 1984. The effect of thermal pretreatment on the anaerobic biodegradability and toxicity of waste activated sludge. Water Res., 18: 1343-1353.

10. Gonze, E., S. Pillot, E. Valette, Y. Gonthier, A. Bernis, 2003. Ultrasonic treatment of an aerobic activated sludge in a batch reactor. Chem. Eng. Process., 42: 965-975. DOI: 10.1016/S02552701(03)00003-5.

11. Chiu, Y.C., C.N. Chang, J.G. Lin and S.J. Huang, 1997. Alkaline and ultrasonic pretreatment of sludge before anaerobic digestion. Water Sci. Technol., 36: 155-162..

12. Barjenbruch, M., O. Kopplow, 2003. Enzymatic, mechanical and thermal pre-treatment of surplus sludge. Adv. Environ. Res., 7: 715-720. DOI: 10.1016/S1093-0191(02)00032-1.

13. Valo, A., H. Carrere, J.P. Delgenes, 2004. Thermal, chemical and thermo-chemical pre-treatment of waste activated sludge for anaerobic digestion. J. Chem. Technol. Biotechnol., 79: 1197-1203. DOI: 10.1002/jctb. 1106.

14. Government of Malaysia 1977. Environmental Quality (Prescribed Premises), (Crude Palm Oil) Regulations 1977. P.U.(A) 342/1977, amended by P.U.(A) $183 / 82$.

15. Collins, A.G., S. Mitra and S.G. Pavlostathis, 1991. Microwave heating for sludge dewatering and drying. J. WPCF., 63: 921-924.

16. Tsai, T.S., 1986. A microwave method for the extraction of cellular ATP. J. Biochem. Bioph. Meth., 13: 343-345. http://www.ncbi.nlm.nih.gov/pubmed/3549846

17. Chu, C.P., B.V. Chang, G.S. Liao, D.S. Jean and D.J. Lee, 2001. Observations on changes in ultrasonically treated waste-activated sludge. Wat. Res., 35: 1038-1046. DOI: 10.1016/S00431354(00)00338-9.

18. Chu, C.P., D.J. Lee, B.V. Chang, C.S. You and J.H. Tay, 2002. "Weak' ultrasonic pre-treatment on anaerobic digestion of flocculated activated biosolids. Wat. Res., 36: 2681-2688.

19. Hogan, F., S. Mormede, P. Clark and M. Crane, 2004. Ultrasonic sludge treatment for enhanced anaerobic digestion. Wat. Sci. Tech., 50: 25-32. http://www.cababstractsplus.org/google/abstract.as $\mathrm{p}$ ? AcNo=20043201210.
20. Clescerl, Lenore, Greenberg, E. Arnold and D. Eaton and rew, 1998. Standard Methods for the Examination of Water and Wastewater. 20th Edn., American Public Health Association, Washington DC., pp: 1000. ISBN: 0-875-53235-7.

21. Erguder, T.H., U. Tezel, E. Guven and G.N. Demirer, 2001. Anaerobic biotransformation and methane generation potential of cheese whey in batch and UASB reactors. Waste Manage., 21:643-650. DOI: 10.1016/S0956-053X(00)00114-8

22. Ahmad, Abdul Latif, Ismail, Suzylawati and Bhatia, Subhash, 2003. Water recycling from Palm Oil Mill Effluent (POME) using membrane technology. Desalination, 157: 87-95. DOI: 10.1016/S0011-9164(03)00387-4.

23. Najafpour, G.D., A.A.L. Zinatizadeh, A.R. Mohamed, M.H. Isa and H. Nasrollahzadeh, 2006. High-rate anaerobic digestion of palm oil mill effluent in an upflow anaerobic sludge-fixed film bioreactor. Process Biochem., 41: 370-379. DOI: 10.1016/j.procbio.2005.06.031.

24. Raj, D.S.S. and Y. Anjaneyulu, 2005. Evaluation of biokinetic parameters for pharmaceutical wastewaters using aerobic oxidation integrated with chemical treatment. Process Biochem., 40: 165-175. DOI: 10.1016/j.procbio.2003.11.056.

25. Oswal, N., P.M. Sarma, S.S. Zinjarde and A. Pant, 2002. Palm oil mill effluent treatment by a tropical marine yeast. Bioresource Technol., 85: 35-37. doi:10.1016/S0960-8524(02)00063-9.

26. Angelidaki, I., S.P. Petersen and B.K. Ahring, 1990. Effects of lipids on thermophilic anaerobic digestion and reduction of lipid inhibition upon addition of bentonite. Appl. Microbiol. Biotechnol., 33: 469-472. DOI: $10.1007 / \mathrm{BF} 00176668$.

27. Cirne, D.G., X. Paloumet, L. Björnsson, M.M. Alves and B. Mattiasson, 2007. Anaerobic digestion of lipid-rich waste-Effects of lipid concentration. Renewable Energ., 32: 965-975. DOI:10.1016/j.renene.2006.04.003.

28. Drewsa, A., M. Vocksa, V. Iversena, B. Lesjeanb and M. Kraumea, 2006. Influence of unsteady membrane bioreactor operation on EPS formation and filtration resistance. Desalination, 192: 1-9. DOI:10.1016/j.desal.2005.04.130. 